\title{
COVID-19 and air pollution: what do we know so far?
}

\author{
Ronan Adler Tavella, Flavio Manoel Rodrigues da Silva Júnior* \\ Programa de Pós Graduação em Ciências da Saúde, Faculdade de Medicina, \\ Universidade Federal do Rio Grande - FURG, Rio Grande, RS, Brasil
}

Histórico do Artigo
Recebido em:
29/05/2020
Aceito em:
04/06/2020
Keywords:
Severe Acute
Respiratory Syndrome
coronavirus;
atmospheric pollution;
China; lockdown

Histórico do Artigo

ABSTRACT

COVID-19, a disease caused by the Severe Acute Respiratory Syndrome coronavirus (SARS-CoV2), was declared a Pandemic in February 2020 and by the end of April more than 200,000 people had died from it. In an attempt to reduce viral transmission, governments around the world have imposed restrictions on internal mobility and lockdown. Almost instantly, information regarding of air pollution reduction traveled as fast as the wind and local and regional studies are starting to be conducted to show this more detailed picture. Moreover, in midst of this scenario, researches concerning the possible association between the spread and lethality of COVID-19 and levels of air pollution also starts to appear, mainly because the current situation appears to be very similar in China and European countries. This brief review aims to address some studies already published on this topic and discuss future directions for the scientific community. The two main topics covered are the relation between air pollution and the spread and lethality of Covid-19 and reduction of air pollution due to quarantine/lockdown. Similar research in other parts of the world will give a more complete picture of the association between air pollution and COVID-19.

COVID-19 e poluição do ar: o que nós sabemos até o momento?

\section{RESUMO}

A COVID-19, uma doença causada pelo novo coronavírus da Síndrome Respiratória Aguda Grave (SARS-CoV-2), foi declarada uma pandemia em fevereiro de 2020 e, no final de abril, mais de 200.000 pessoas haviam morrido por conta da doença. Na tentativa de reduzir a transmissão viral, governos de todo o mundo impuseram restrições à mobilidade interna e de bloqueio. Quase instantaneamente, informações sobre a redução da poluição do ar viajaram tão rápido quanto o vento e estudos locais e regionais estão começando a ser realizados para mostrar esse quadro de maneira

Palavras-chave:

Coronavírus da

Síndrome Respiratória

Aguda Grave; poluição atmosférica; China; confinamento mais detalhada. Além disso, em meio a esse cenário, pesquisas sobre a possível associação entre a disseminação e a letalidade da COVID-19 e os níveis de poluição do ar também começam a aparecer, principalmente porque a situação atual parece ser muito semelhante na China e nos países europeus. Esta breve revisão visa abordar alguns estudos já publicados sobre este tópico e discutir orientações futuras para a comunidade científica. Os dois principais tópicos abordados são: a relação entre a poluição do ar e a propagação e letalidade do Covid-19 e a redução da poluição do ar devido à quarentena / bloqueio. Pesquisas semelhantes em outras partes do mundo fornecerão um cenário mais completo da associação entre poluição do ar e COVID-19.

\section{Introduction}

The new Severe Acute Respiratory Syndrome coronavirus (SARS-CoV-2) disease (COVID-19) has taken the world to a state of attention and precaution never seen before. The outbreak of COVID-19 is an ongoing global epidemic event which started in Wuhan, China, in late 2019. This outbreak was firstly declared as a Public Health Emergency of International Concern on 30 January and then it was officially confirmed as Pandemic on 11 February (1). As of April 26 ${ }^{\text {th }}, 2020$, there have been 2,965,711 confirmed cases and 205,656 deaths reported globally (2).

\footnotetext{
* Corresponding author: f.m.r.silvajunior@gmail.com (Silva Júnior F.M.R)
} 
To avoid virus apread, governments around the world began to implement actions, such as, social distancing, stopping activities considered non-essential, reducing or stopping public transportation, among others, which led countries to almost a complete lockdown (3). As a consequence of this lockdown, space agencies as National Aeronautics and Space Administration (NASA) and European Space Agency (ESA), have been reporting a sharp drop in levels of air pollution in multiple regions across the globe (4-6).

Since the study by Cui et al. (7), during the SARS outbreak in 2002, there is an assumption that air pollution may be linked in some way to a higher degree of viral infections. In the case of COVID-19, early studies concluded that among the risk factors are older age, history of smoking, respiratory tract problems, hypertension and heart disease (8-10). Apart from age and smoking factors, exposures to high levels of air pollutants are associated with the development of hypertension (11), heart and cardiovascular diseases $(12,13)$ and, also, different respiratory problems (14-16).

In light of the above, with the new coronavirus outbreak, some new researches have been carried out involving air pollution with different issues of the Covid-19 disease, be it for reasons of dissemination, lethality or other outcomes. Thus, the aim of this study was to review and discuss studies that involve the relation between air pollution and Covid-19, either at the global, regional or local level.

\section{Methods}

\subsection{Search Strategy and Data Collection}

The review was conducted based on a search in the database MEDLINE (United States National Library of Medicine), on April 20, 2020. The search terms used were: "COVID19" OR "SARS-CoV-2" OR "severe acute respiratory syndrome coronavirus 2" AND "pollution" OR "contamination" OR "air pollution". The search strategy aimed to find published studies from any country and language. Original articles, short communications, editorials or letters to editor were included in the study, as long as they addressed the theme of environmental pollution and COVID-19. Studies addressing contamination in a hospital setting were excluded.

The first phase of the screening was carried out by reading the title and abstract of the papers considering the inclusion criteria. All articles not excluded in the first evaluation were read in full-text for inclusion in the study. All articles were independently assessed by two researchers (RAT and FMRSJ) and the data were extracted in a similar way.

Data extraction was performed independently, and the following information were recorded from each selected article: title, date of submission, acceptance and/or publication, country studied, type of study, objective, data and results, conclusion and reference.

\section{Results}

Thirty-six studies were extracted from the search on MEDLINE and after the first evaluation, 30 articles were excluded. In the second stage, the 6 articles were read in fulltext and all included in this review, as they met the inclusion criteria adopted in the research. A brief summary of the studies is included in Table 1.

The studies that addressed the relationship between air pollution and COVID-19 focused on 5 countries (China, Italy, Spain, Germany and France). Papers were accepted for publication between March 24 and April 9, 2020 and the average time between submission and acceptance was nine days (ranging from 0 to 35 days). The central themes 
of the papers include: the relation between air pollution and the spread and lethality of COVID-19 (17-19) and reduction of air pollution due to quarantine/lockdown (20-22).

Table 1 - Brief summaries of papers found on Air Pollution and COVID-19

\begin{tabular}{llll}
\hline \multicolumn{1}{c}{ Study } & \multicolumn{1}{c}{ Date } & Country & \multicolumn{1}{c}{ Type } \\
\hline Can & Submitted: & Italy & Full length \\
atmospheric & March 22, & & article \\
pollution be & 2020. & & \\
considered a co- & & \\
factor in & Accepted: & & \\
extremely high & March 24, & \\
level of SARS- & 2020. & & \\
CoV-2 lethality & & & \\
in Northern & & \\
Italy? & &
\end{tabular}
Relation between air The article is based on The article concludes pollution and the findings from other studies that air pollution can spread and lethality of that report that the severe be a cofactor for the COVID-19 conditions of COVID -19 are high lethality rates of related to hyperactivation of SARS-CoV-2 in the innate immune system, northern Italy, changing numerous although it also cytokines and growth factors. highlights factors such At the same time, authors as the age structure of reveal that air pollution the affected increases the chance of population, the great developing chronic differences between respiratory problems and that Italian regional health prolonged exposure to systems, capacity of pollution leads to a chronic intensive care units in inflammatory stimulus, the region and the involving cytokines that are prevention policies also stimulated during the adopted by the worsening of COVID-19. government have played a major role in the spread and fatality the spread and fatality
of SARS-CoV-2, presumably even more than air pollution

COVID-19 as a Submitted: China Letter to Reduction of air The authors present data and factor March 5, influencing air 2020 . pollution?

Published: April 9 2020.

Air Pollution and the Novel COVID -19

Accepted: April 3, 2020.

Disease: a

Putative

Disease

Risk Factor

\section{Published:}

April 15,

2020.

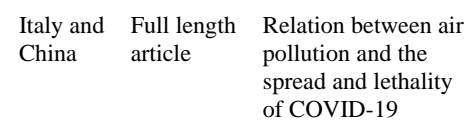

\begin{tabular}{|c|c|c|c|c|}
\hline $\begin{array}{l}\text { Assessing } \\
\text { nitrogen } \\
\text { dioxide (NO2) } \\
\text { levels as a } \\
\text { contributing } \\
\text { factor to } \\
\text { coronavirus } \\
\text { (COVID-19) } \\
\text { fatality }\end{array}$ & $\begin{array}{l}\text { Submitted: } \\
\text { April 7, } \\
2020 . \\
\text { Accepted: } \\
\text { April 8, } \\
2020 . \\
\\
\text { Published: } \\
\text { April 11, } \\
2020 .\end{array}$ & $\begin{array}{l}\text { Italy, } \\
\text { Spain, } \\
\text { France } \\
\text { and } \\
\text { Germany }\end{array}$ & $\begin{array}{l}\text { Short } \\
\text { Communic } \\
\text { ation }\end{array}$ & $\begin{array}{l}\text { Relation between air } \\
\text { pollution and the } \\
\text { spread and lethality } \\
\text { of COVID-19 }\end{array}$ \\
\hline
\end{tabular}

The study highlights $\mathrm{NO}_{2}$ as a key component among air pollutants for the

development of several

diseases. The results show the existence of a relationship between high levels of $\mathrm{NO}_{2}$, together with a low regional dispersion of this compound in the troposphere, and mortality by COVID-19. As a main finding, almost $80 \%$ of deaths in these 4 countries occurred in areas with a $\mathrm{NO}_{2}$ concentration greater than $100 \mu \mathrm{mol} / \mathrm{m}^{2}$. itself.

Researchers suggest that the reduction of atmospheric pollution resulting from the

quarantine carried out by China and other countries will substantially reduce the number of deaths due to this reason in the world. Countries must make their

predictions just as China did.

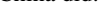

The scenarios shown

in China and Italy reveal a possible relationship between air pollution and the number of COVID-19 cases. However, they address that epidemiological studies must be carried out to prove this theory.

The results indicate that long-term exposure to this pollutant may be one of the most important contributors to the high fatality caused by the SARS-CoV-2 virus in the regions assessed and perhaps worldwide.

(n)




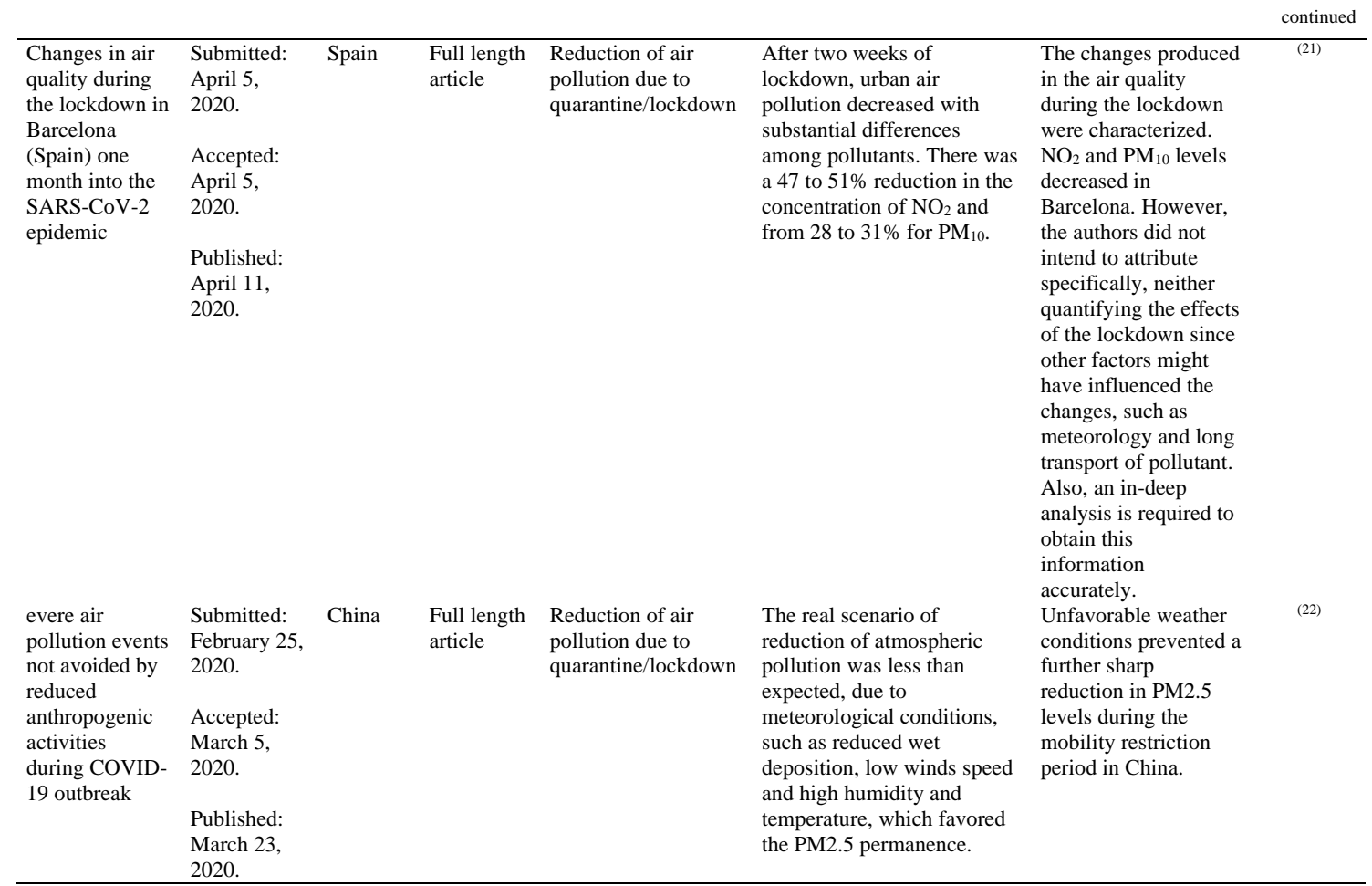

\section{Discussion}

The novel coronavirus disease, caused by SARS-CoV-2, is in the midst of worldwide panic and global health concern since December 2019. With this emerging battle against the virus, World Health Organization has strategized actions that include interruption of human-human contact, isolate patients at early stages, address crucial mysteries about the virus and accelerate research. At this juncture, it is tremendously vital to find and understand possible factors that are linked to the spread, contamination and lethality of this virus. In this regard, air pollution has been receiving attention, not only because of sharp drop in levels of air pollution around the globe, but also because previous studies with SARS virus (SARS-CoV) suggested that high air pollution might facilitate the spread of the virus (7). Furthermore, it is important to note that recent research has shown many similarities between SARS-CoV-2 and SARS-CoV (23).

Air pollutants are compounds present in the atmospheric matrix that may occur from anthropogenic activities (mostly fossil fuel combustion from vehicles and power plants) and natural processes. The main atmospheric pollutants evaluated in the studies present in this review were nitrogen dioxide $\left(\mathrm{NO}_{2}\right)$, sulfur dioxide $\left(\mathrm{SO}_{2}\right)$, ozone $\left(\mathrm{O}_{3}\right)$ and particulate matter with a diameter less than 10 and $2.5\left(\mathrm{PM}_{10}\right.$ and $\left.\mathrm{PM}_{2.5}\right)$. World Health Organization have set health-based Air Quality Standards for air pollutants due to the high evidence that these could lead to several outcomes that impact health $(24,25)$.

In this sense, knowing the importance of air quality for maintaining quality of life and given the scenario of this recent pandemic where we have more questions than answers, we intend to discuss two main points involving the relation between air pollution and COVID-19 (air pollution and disease spread and severity, and the reduction of air pollution in lockdown scenarios) and provide input for future directions.

\subsection{Air pollution and Covid-19 spread and fatality}

According to Huang et al. (26) the infections caused by the virus vary and can range 
from being mild (i.e., not showing any symptoms) to more severe, which in some cases can lead to hospitalization, followed by an acute respiratory distress syndrome (ARDS) and death.

ARDS is a dramatic event whose treatment is usually only supportive, requiring mechanical ventilation. Regardless of the etiology, a hyper-activation of immune innate system is thought to have a paramount role in this condition (27). In this context, Conticini et al. (17) pointed that similar evidences have been reported in patients affected by severe viral pneumoniae such as SARS (28) and MERS (29) and an immune dysregulation is thought to be responsible of a worse outcome in patients affected by COVID-19. In addition, both Conticini et al. (17) and Ogen (19) highlights that air pollution represents one of the most well-known causes of prolonged inflammation, eventually leading to an innate immune system hyper-activation (30-34). Moreover, the main risk factors for COVID-19 to evolve from mild to more severe are older age, history of smoking, impaired respiratory system, hypertension and heart disease (8-10). Other studies suggest that diabetes should also be considered a risk factor (35). With that in mind, some concern is developed, mainly because apart from age and smoking habits, both hypertension (11), impairments in the respiratory system (14-16), heart disease $(12,13)$, diabetes $(11)$ are comorbidities that have a relation, already described, with chronic exposure to high levels of air pollutants. However, since prolonged exposure to air pollutants could induce persistent modifications of the immune system and lead to the development of health problems, short-term changes in air quality may not be sufficient to alter this damaging cycle, affirm Conticini et al. (17). On the other hand, Cui et al. (7) studying the relationship between air pollution and the severity of SARS showed that the association between the rate of air pollution in short-term exposures and the mortality rate was even stronger than at the same rate considering long-term exposures. In this sense, considering that prolonged exposure (and perhaps severe exposure in the short term) can compromise the immune system and the respiratory tract, it is reasonable to believe that residents of polluted areas around the world can live with high rates of lethality by COVID-19 in their regions.

Diseases, or comorbidities, possibly developed by air pollution that predispose humans to viral infections are not the only problem that directly relates this issue to COVID-19. As discussed by Martelletti \& Martelleti (18), in his study carried out in the northern region of Italy, there is a "visible" correlation between elevated concentration of air pollutants and the high spread and mortality rate of Covid-19. In this context, these authors suggest that air pollutants are most likely direct to facilitate the longevity of virus particles in favorable climate conditions and become more aggressive in an immune system already aggravated by these harmful substances. The author bases his hypothesis in the study performed by Cui et al. (7), during the SARS outbreak, and a recent SIMA (Società Italiana di Medicina Ambientale) analysis of Covid-19 diffusion in Italy (36), in which it propose that the atmospheric particulate matter exercises a carrier action along with the virus. The authors point out that the connection made by them needs further investigation due to the lack of data and causality, but, they report that China has faced a near identical situation to Italy with its epicenter of the COVID-19 pandemic, where elevated concentrations of air pollutants were present in the regions mostly affected. In this context, similar situations seem to be repeating throughout the world, in other regions such as New York, USA, and São Paulo, Brazil.

Although the transmission pathways most associated with SARS-CoV-2 are via touching infected surfaces (carrying the virus through the mouth, nose, or eyes) and transmission via droplets containing virus exhaled through the respiratory tract of the infected patient, the contribution of other pathways, including environmental pathways, 
should be further investigated. These routes include the inhalation of atmospheric particles contaminated with the virus and this can be extensively dangerous in developing countries that experience high levels of atmospheric particulate matter (37).

In addition to what has been exposed so far, when assessing air pollution, it is important to take into account not only the concentration, chemical and physical profile of the substances that compose it, but also analyze its spatial distribution and the atmosphere conditions, performed by Ogen (19). Results of his study shows that almost $80 \%$ of all fatal cases in Italy, France, Spain and Germany were in five regions located in north of Italy and central Spain. Additionally, the same five regions show the highest $\mathrm{NO}_{2}$ concentrations combined with downwards airflow which prevents an efficient dispersion of air pollution. In line with what has already been discussed, these results amplify the suggestion that the long-term exposure to air pollutants may be one of the contributors to the high fatality and spread rate caused by the SARS-CoV-2 in these regions and maybe across the whole world. Hence, poisoning our environment means poisoning our own body and when it experiences a chronic respiratory stress, its ability to defend itself from infections is limited.

\subsection{COVID-19 and reduction of air pollution}

As a measure to curb the spread of COVID -19's within its borders, governments around the world began to adopt increasingly restrictive containment actions to mitigate the effects of the disease and consecutively enable their health systems to act without extrapolating their capacity. Cases isolation, contact tracing, and quarantine and mitigation measures, including lockdown and social (or personal) distancing, are among the main actions.

Containment actions have caused many of the main sources of air pollution to be extremely reduced (i.e. vehicle emissions, factory production). As a result, global space agencies have been presenting data and disseminating information about the reduction of the main air pollutants in different regions of the world (4-6). It is important to highlight the use of ESA Sentinel-5 Precursor space-borne satellite in providing this information, mainly because most of the studies present in this review use or interpret its results based on data generated by this satellite.

The studies by Dutheil et al. (20), Tobias et al. (21) and Wang et al. (22), were the studies found in this review that verified and discussed the decrease in air pollution. Two of them were based on results from China and one in Barcelona. Tobías et al. (21) showed that there was a high decrease in the concentration of $\mathrm{NO}_{2}, \mathrm{PM}_{10}$ and $\mathrm{SO}_{2}$, during the study. The greatest decrease was observed in the concentration of $\mathrm{NO}_{2}$, a compound characterized by being emitted through combustion processes, such as urban traffic and industrial operations, activities directly affected by the lockdown. However, there was an unexpected increase in the concentration of $\mathrm{O}_{3}$, and this probably occurred due to lower titration of $\mathrm{O}_{3}$ by nitrogen oxides (NO) and the decrease of NOx in a volatile organic compound limited environment. Similar decreases were seen in China, as demonstrated by the images approached by Dulthein et al. (20) and the simulations carried out by Wang (22). However, it is important to note how weather changes influence air pollution and how their data against COVID-19 and lockdown should be interpreted. Both Tobias (21) and Wang (22) reported that other factors might have influenced the changes, such as meteorology and regional and long transport of pollutant. Implying that further analysis are required to obtain this information accurately.

As mentioned before, the decrease in air pollution due to quarantine possibly does not decrease the fatality of COVID-19 cases, since increased exposure to air pollutants can 
lead to the development of health problems that weaken an individual's organism, leaving it more vulnerable to a more severe outcome from COVID-19, and a decrease in exposure to these contaminants does not generate an immediate improvement in health. However, the study by Dulthein et al. (20) raises a possible paradox regarding the issues of fatality in Covid-19, because yes, this disease is plaguing the world and leaving a high number of deaths wherever it goes, on the other hand the decrease in pollution may be saving more lives than Covid-19 is taking. This assumption is made based on studies that use calculations to predict the number of fatalities, as well as public health expenses, resulting from the level of atmospheric pollution in a given region $(16,25)$. However, despite the possibility that the lockdown, with its consequent decrease in air pollution, is saving lives, this does not diminish the frightening scenario that Covid-19 presents to the world, thereby evidencing the need for further actions by governments and responsible agencies in assessing air pollution as a very likely cofactor for high number of fatalities in the face of the pandemic that we are experiencing.

\subsection{Future directions}

Whilst China, European countries and perhaps the USA are emerging from the critical period of this pandemic, the uncertainties related to the countries of the southern hemisphere, which are underdeveloped and extremely polluted, only increase the urgency for responses to this enigmatic virus. Obviously, clinical, epidemiological and therapeutic concerns are advancing more quickly and find greater attention from newspapers, websites and the crowded lines of prestigious journals, but environmental concern cannot be neglected for a number of reasons that include the vulnerability of populations living in extremely polluted areas, without access to drinking water and sanitation, the possibility that environmental matrices such as water, sewage and air are important vehicles in the transmission of SARS-CoV-2 and lastly, the positive and measurable consequences to the environment resulting from the blockade actions to avoid the rapid spread of the virus in urban areas.

The first concern is that studies conducted in different parts of the world must be performed and (please) have room in scientific journals, because one thing that this virus has taught everyone is that it is extremely versatile, mutable, and brings local and regional particularities that when well understood can be the difference between people's life and death. Regarding the relation with air pollution, the hypotheses raised by the studies included in this review need to be thoroughly tested in further researches that contemplate different scenarios but conducted with sufficient scientific rigor to provide concrete evidence. If the connection between air pollution and the severity of Covid-19 cases is proven, we dare suggesting that people living in environments with extremely polluted air should be part of the risk group, together with the elderly, bearer of chronic noncommunicable diseases, immunosuppressed patients and those with respiratory problems, since this condition would debilitate the person as much as the other factors already reported that increase the risk of complications to this disease.

Given the lack of knowledge about the totality of the transmission routes of SARS-CoV2, considering that other respiratory viruses use air as a means of propagation (38) and savvy that the survival of SARS-CoV-2 in the environment exceeds the scale of days (37), it is reasonable to believe that this matrix can be a vehicle for transporting and transmitting the virus. If this is confirmed, the use of protective masks and extra care when leaving the house to go to the bakery will be constant scenes in our daily lives.

Mitigating the discussion, a positive side of this pandemic has been the constant reports of improvements in environmental quality in different parts of the world due to the 
reduction of urban mobility and industrial activities. Dutheil and his collaborators (20), in their letter to the editor of the journal Environmental Pollution, present an impressive number of approximately 100,000 lives being preserved in China due to restrictive mobility measures. This calculus should be extended to all parts of the world, especially considering that the virus has been acting in large metropolises of the western world and measures of social isolation are already being taken since February or March 2020.

If, on the one hand, at the end of the pandemic the world will have a sad number of losses due to the severity of the infection, on the other hand, the number of lives preserved with social isolation, both by decreasing the transmission speed of the virus and by reducing air pollution will bring humanity hopes for a more harmonious relationship with the environment.

\section{References}

1. World Health Organization [Internet]. Coronavirus disease (COVID-19) - events as they happen; 2020 [Accessed 2020 Apr 26]. Available from: https://wwwwhoint/emergencies/diseases/novelcoronavirus-2019/events-as-theyhappen.

2. Worldometer [Internet]. COVID-19 Coronavirus pandemic; 2020 [Accessed 2020 Apr 26]. Available from: https://www.worldometers.info/coronavirus/.

3. Signorelli C, Scognamiglio T, Odone A. COVID-19 in Italy: impact of containment measures and prevalence estimates of infection in the general population. Acta Bio-medica: Atenei Parmensis 2020; 91(3-S): 175-179.

4. ESA [Internet]. Coronavirus lockdown leading to drop in pollution across Europe; 2020 [Accessed 2020 Apr 26]. Available from:

https://www.esa.int/Applications/Observing the Earth/Copernicus/Sentinel5P/Coronavirus_lockdown_leading_to_drop_in_pollution_across_Europe.

5. NASA [Internet]. Airborne Nitrogen Dioxide Plummets Over China; 2020a [Accessed 2020 Apr 26]. Available from: https://earthobservatory.nasa.gov/images/146362/airborne-nitrogen-dioxideplummets-over-china.

6. NASA [Internet]. NASA Satellite Data Show 30 Percent Drop In Air Pollution Over Northeast U.S; 2020b [Accessed 2020 Apr 26]. Available from: https://www.nasa.gov/feature/goddard/2020/drop-inair-pollution-over-northeast.

7. Cui Y, Zhang ZF, Froines J, Zhao J, Wang H, Yu SZ, Detels R. (2003). Air pollution and case fatality of SARS in the People's Republic of China: an ecologic study. Environmental Health 2003; 2(1): 15.

8. Chen M, Fan Y, Wu X, Zhang L, Guo T, Deng K, et al. Clinical characteristics and risk factors for fatal outcome in patients with 2019-coronavirus infected disease (COVID-19) in Wuhan, China. The Lancet 2020; 80(6): 656-665.

9. Liu W, Tao ZW, Wang L, Yuan ML, Liu K, Zhou L, et al. Analysis of factors associated with disease outcomes in hospitalized patients with 2019 novel coronavirus disease. Chinese medical journal 2020; 133(9): 1032-1038.

10. Wu C, Chen X, Cai Y, Zhou X, Xu S, Huang H, et al. Risk factors associated with acute respiratory distress syndrome and death in patients with coronavirus disease 2019 pneumonia in Wuhan, China. JAMA internal medicine. 2020; e200994.

11. Shin S, Bai L, Oiamo TH, Burnett RT, Weichenthal S, Jerrett M, et al. Association between road traffic noise and incidence of diabetes mellitus and hypertension in Toronto, Canada: a population-based cohort study. Journal of the American Heart Association 2020; 9(6): e013021.

12. Pope III CA, Burnett RT, Thurston GD, Thun MJ, Calle EE, Krewski D, Godleski JJ. Cardiovascular mortality and long-term exposure to particulate air pollution: epidemiological evidence of general pathophysiological pathways of disease. Circulation 2004; 109(1): 71-77.

13. Gan WQ, Davies HW, Koehoorn M, Brauer M. Association of long-term exposure to community noise and traffic-related air pollution with coronary heart disease mortality. American journal of epidemiology 2012; 175(9): 898-906.

14. Chen TM, Kuschner WG, Gokhale J, Shofer S. Outdoor air pollution: nitrogen dioxide, sulfur dioxide, 
and carbon monoxide health effects. The American journal of the medical sciences 2007; 333(4): 249256.

15. Beelen R, Hoek G, van Den Brandt PA, Goldbohm RA, Fischer P, Schouten LJ, et al. Long-term effects of traffic-related air pollution on mortality in a Dutch cohort (NLCS-AIR study). Environmental health perspectives 2008; 116(2): 196-202.

16. Hoek G, Krishnan RM, Beelen R, Peters A, Ostro B, Brunekreef B, et al. Long-term air pollution exposure and cardio-respiratory mortality: a review. Environmental health 2013; 12(1): 43.

17. Conticini E, Frediani B, Caro D. Can atmospheric pollution be considered a co-factor in extremely high level of SARS-CoV-2 lethality in Northern Italy? Environmental Pollution 2020; 114465.

18. Martelletti L, Martelletti P. Air pollution and the novel Covid-19 disease: a putative disease risk factor. SN Comprehensive Clinical Medicine 2020; 1-5.

19. Ogen Y. Assessing nitrogen dioxide (NO2) levels as a contributing factor to the coronavirus (COVID19) fatality rate. Science of the Total Environment 2020; 138605.

20. Dutheil F, Baker JS, Navel V. COVID-19 as a factor influencing air pollution? Environmental Pollution 2020; 263(Pt A):114466.

21. Tobías A, Carnerero C, Reche C, Massagué J, Via M, Minguillón MC, et al. Changes in air quality during the lockdown in Barcelona (Spain) one month into the SARS-CoV-2 epidemic. Science of The Total Environment 2020; 138540.

22. Wang P, Chen K, Zhu S, Wang P, Zhang H. Severe air pollution events not avoided by reduced anthropogenic activities during COVID-19 outbreak. Resources, Conservation and Recycling 2020; 158: 104814.

23. Petrosillo N, Viceconte G, Ergonul O, Ippolito G, Petersen E. COVID-19, SARS and MERS: are they closely related? Clinical Microbiology and Infection 2020; 26(6):729-734.

24. World Health Organization. WHO Air quality guidelines for particulate matter, ozone, nitrogen dioxide and sulfur dioxide: global update 2005: summary of risk assessment (No. WHO/SDE/PHE/OEH/06.02). Geneva: World Health Organization, 2006.

25. Abe KC, Miraglia SGEK. Health impact assessment of air pollution in São Paulo, Brazil. International journal of environmental research and public health 2016; 13(7): 694.

26. Huang C, Wang Y, Li X, Ren L, Zhao J, Hu Y, et al. Clinical features of patients infected with 2019 novel coronavirus in Wuhan, China. The Lancet 2020; 395(10223): 497-506.

27. Aisiku IP, Yamal JM, Doshi P, Benoit JS, Gopinath S, Goodman JC, et al. Plasma cytokines IL-6, IL8 , and IL-10 are associated with the development of acute respiratory distress syndrome in patients with severe traumatic brain injury. Critical care 2016; 20(1): 288.

28. Wong CK, Lam CWK, Wu AKL, Ip WK, Lee NLS, Chan HIS, et al. Plasma inflammatory cytokines and chemokines in severe acute respiratory syndrome. Clinical \& Experimental Immunology 2004; 136(1): 95-103.

29. Min CK, Cheon S, Ha NY, Sohn KM, Kim Y, Aigerim A, et al. Comparative and kinetic analysis of viral shedding and immunological responses in MERS patients representing a broad spectrum of disease severity. Scientific reports 2016; 6(1): 1-12.

30. Pope III CA, Bhatnagar A, McCracken JP, Abplanalp W, Conklin DJ, O'Toole T. Exposure to fine particulate air pollution is associated with endothelial injury and systemic inflammation. Circulation research 2016; 119(11): 1204-1214.

31. Che L, Jin Y, Zhang C, Lai T, Zhou H, Xia L, et al. Ozone-induced IL-17A and neutrophilic airway inflammation is orchestrated by the caspase-1-IL-1 cascade. Scientific reports 2016; 6(1): 1-11.

32. Perret JL, Bowatte G, Lodge CJ, Knibbs LD, Gurrin LC, Kandane-Rathnayake R, et al. The DoseResponse association between nitrogen dioxide exposure and serum interleukin- 6 concentrations. International journal of molecular sciences 2017; 18(5): 1015.

33. Kurai J, Onuma K, Sano H, Okada F, Watanabe M. Ozone augments interleukin-8 production induced by ambient particulate matter. Genes and Environment 2018; 40(1): 14.

34. Tsai DH, Riediker M, Berchet A, Paccaud F, Waeber G, Vollenweider P. Effects of short-and longterm exposures to particulate matter on inflammatory marker levels in the general population. Environmental Science and Pollution Research 2019; 26(19): 19697-19704.

35. Fang L, Karakiulakis G, Roth, M. Are patients with hypertension and diabetes mellitus at increased 
risk for COVID-19 infection? The Lancet Respiratory Medicine 2020; 8(4): e21.

36. Setti L, Passarini F, De Gennaro G, Di Gilio A, Palmisani J, Buono P, et al. Position Paper Relazione circa l'effetto dell'inquinamento da particolato atmosferico e la diffusione di virus nella popolazione. SIMA-Società Italiana di Medicina Ambientale; 2020.

37. Qu G, Li X, Hu L, Jiang G. An Imperative Need for Research on the Role of Environmental Factors in Transmission of Novel Coronavirus (COVID-19). Environ Sci Technol 2020; 54(7): 3730-3732.

38. Chen G, Zhang W, Li S, Zhang Y, Williams G, Huxley R, et al. The impact of ambient fine particles on influenza transmission and the modification effects of temperature in China: a multi-city study. Environment international 2017; 98: 82-88. 